mucosa or of the nails. Four women had taken iron tablets for long periods, but not for the six months previous to this investigation. During this time they had not observed any change in the ozaena.

The Table contains the results of the haematological investigations. All patients had haemoglobin, haematocrit, and red cell count within normal limits. Serum iron was normal in eight patients, and all had normal total iron-binding capacity. One male patient (Case 8) had a serum iron of $75 \mu \mathrm{g} . / 100 \mathrm{ml}$. and a total iron-binding capacity of $280 \mu \mathrm{g} . / 100 \mathrm{ml}$., with a saturation index of 27 , but with high values for haemoglobin and red cells. The iron content of his marrow was low, but iron was definitely present. Therefore, in spite of the reduced serum iron, we conclude that he was not iron-deficient.

\section{Comments}

In our small series of ozaena patients iron deficiency could not be demonstrated. We have no explanation for the discrepancy between our findings and those of Bernát (1966). However, ozaena may possibly result from several disease mechanisms, and iron deficiency may be a predisposing factor which leads to ozaena only in the presence of one or more other factors, which may be uncommon in this country. While general conclusions should not be drawn, we can only state that iron deficiency does not appear to be important in the pathogenesis of ozaena in our series of patients.

\section{Summary}

It has previously been suggested that ozaena is a special manifestation of iron deficiency (Bernát, 1966). However, iron deficiency is common in Norway, but ozaena is rare. Among 24,176 patients we found nine with ozaena. None of these had evidence of iron deficiency.

\section{REFERENCES}

Bernát, I. (1966). Die Ozaena Eine Manifestation der Eisenmangelkrankheil. Budapest

Dacie, J. V., and Lewis, S. M. (1963). Practical Haematology, 3rd ed. Natvig, H., and Vellar, O. D. (1967). Acta med. scand., 182, 193.

\title{
Improved Control of Long-term Anticoagulant Therapy
}

\author{
R. D. EASTHAM,* M.D., F.C.PATH., D.C.P., DIPL.PATH.
}

Brit. med.7., 1968, 2, 337-340

Though anticoagulant therapy reduces the incidence of additional thrombosis and pulmonary embolism during the first few weeks after myocardial infarction, further attacks of thrombosis at various sites can occur subsequently during long-term oral anticoagulant treatment. Control of such treatment is not entirely satisfactory, and attempts have been made both to improve such control and to enable laboratories to report comparable results (Biggs and Denson, 1967 ; Poller, 1964).

By means of an activated partial thromboplastin clotting test in-vitro evidence of plasma hypercoagulability was found after acute haemorrhage and also in association with carcinoma; at the same time a rough direct relation between this clotting test and the corresponding prothrombin ratio during oral anticoagulant treatment was recorded (Eastham and Morgan, 1964). During 1967 both tests were performed on all inpatients and outpatients treated with oral anticoagulants. Examination of the results obtained suggests that the activated partial thromboplastin clotting-time is more useful than the prothrombin clotting-time as an indicator either of inadequate treatment or of overtreatment with consequent bleeding.

\section{Patients and Methods}

Blood samples were received from inpatients treated with oral anticoagulants. In addition regular samples of blood were obtained from a total of 103 outpatients during 1967, collected on Tuesdays between 9 and 11.30 a.m. and tested within five hours of collection. These patients were placed in three groups.

"Arterial Lesions."-(1) Nineteen men (aged 40-79 years) without angina of effort after myocardial infarction: one was a diabetic and two had suffered two attacks of infarction. (2) Twenty-two men and four women (38-73 years) with angina of effort after myocardial infarction: five men and one woman

- Consultant Pathologist to the Frenchay/Cossham Group of Hospitals, Bristol (Department of Pathology, Frenchay Hospital, Bristol). after two attacks of infarction and one male diabetic aged 52 after three attacks of infarction. (3) Five men and one woman (47-66 years) after carotid artery thrombosis. (4) One man and one woman (45-47 years) after cerebrovascular accidents. Of these 53 patients 42 were treated with phenindione, 11 with warfarin sodium, and one with a course of each drug.

"Venous Lesions."-(1) Six men and 12 women (26-69 years) after deep vein thrombosis or thrombophlebitis which developed in two of the women after surgical operations and in one woman after myocardial infarction. (2) Thirteen men and eight women (24-69 years) after attacks of pulmonary embolism, which occurred after surgical operations in two men, and with clinical evidence of deep leg vein thrombosis or thrombophlebitis in five men and one woman; two men developed pulmonary embolism after myocardial infarction. Thirty of these patients were treated with phenindione and nine with warfarin sodium.

Mitral Valve Lesions.-Of the six women (44-56 years) and five men (39-55 years) in this group, three women and five men had suffered from embolic attacks, one woman was in congestive cardiac failure, one woman had developed thrombophlebitis, and one woman was given prophylactic anticoagulant following the development of auricular fibrillation. Nine of these patients received phenindione, and two received warfarin sodium.

A total of 913 results from these patients were examined. No results were included in the series until oral anticoagulants had been continued for at least 14 days, though some tests were taken during "tailing-off" of treatment.

Blood Samples.-Plastic disposable syringes were used to obtain samples of venous blood with minimal stasis, $1.8 \mathrm{ml}$. of blood being added to $0.2 \mathrm{ml}$. of $3.8 \%$ sodium citrate solution in polystyrene containers. These were centrifuged to produce platelet-poor plasma.

One-stage Prothrombin Ratio.-An EEL Prothrombinmeter, rabbit-brain thromboplastin (Diagen from Diagnostic Reagents 
Ltd.), and pooled normal control plasma were used and an estimation was made by the method of Quick (1942). The daily dose of oral anticoagulant was adjusted to maintain the ratio of the patient's clotting-time to the control plasma clotting-time between 1.5 and 2.5 and as near to 2 as possible (roughly equivalent to a "prothrombin concentration" of $12-30 \%$ derived from saline dilutions of normal plasma).

Activated Partial Thromboplastin Clotting-time.-A working bentonite suspension of $2 \mathrm{mg}$. $/ \mathrm{ml}$. saline was prepared from a stock bentonite suspension $(20 \mathrm{mg} . / \mathrm{ml}$. saline). A working solution of soya bean extract $(0.2 \mathrm{~g} . / 100 \mathrm{ml}$. saline $)$ was made up in $2-\mathrm{ml}$. aliquots and kept at $-40^{\circ} \mathrm{C}$. until required, from a stock solution of inosithin $(5 \mathrm{~g} . / 100 \mathrm{ml}$. saline) kept at $-40^{\circ} \mathrm{C}$. $0.1 \mathrm{ml}$. of working bentonite suspension plus $0.1 \mathrm{ml}$. of working soya bean extract-that is, platelet substrate substitute-were warmed in a tube at $37^{\circ} \mathrm{C}$. Then $0.2 \mathrm{ml}$. of plasma was added, mixed, and left at $37^{\circ} \mathrm{C}$. for not less than three minutes and not more than eight minutes to ensure complete activation of plasma contact factors without subsequent decay. Then $0.2 \mathrm{ml}$. of $\mathrm{M} / 40$ calcium chloride solution was added, and the time taken to clot was recorded to the nearest second in an EEL Prothrombinmeter (Eastham, 1962). The normal clotting-time $=38.6 \pm 2.9$ ( \pm 1 S.D.) seconds (51 control subjects), with a range of $32-44$ seconds.

\section{Results}

The direct correlation which exists between the activated plasma partial thromboplastin clotting-time and the prothrombin ratio is shown in Table I. Patients with arterial lesions appear to have relatively higher partial thromboplastin clottingtimes at a given prothrombin ratio than do patients with venous lesions. This difference between the two clinical groups of patients is given in Table I. As a corollary of this a higher incidence of normal or nearly normal activated plasma clottingtimes had been found in the results from the patients with venous lesions, when prothrombin ratios showed evidence of anticoagulant action, Table II.

Since the relation between the activated plasma clotting-time and the prothrombin clotting-time is a direct one but the spread about the mean values is wide, 90 replicate estimations of the partial thromboplastin clotting-time performed on various

Table I.-Differences Between Patients with Arterial and Venous Lesions

\begin{tabular}{|c|c|c|c|c|c|}
\hline \multirow{3}{*}{$\begin{array}{c}\text { Prothrom- } \\
\text { bin } \\
\text { Ratio }\end{array}$} & \multicolumn{5}{|c|}{ Activated Plasma Partial Thromboplastin Clotting-times } \\
\hline & \multicolumn{2}{|c|}{$\begin{array}{l}\text { Arterial Lesions } \\
\text { (53 Patients) }\end{array}$} & \multicolumn{2}{|c|}{$\begin{array}{c}\text { Venous Thromboses } \\
\text { (39 Patients) }\end{array}$} & \multirow{2}{*}{$\begin{array}{c}\text { Significance } \\
\text { of } \\
\text { Difference }\end{array}$} \\
\hline & $\begin{array}{l}\text { No. of } \\
\text { Tests }\end{array}$ & $\begin{array}{l}\text { Seconds } \\
\pm \text { S.D. }\end{array}$ & $\begin{array}{l}\text { No. of } \\
\text { Tests }\end{array}$ & $\begin{array}{l}\text { Seconds } \\
\pm \text { S.D. }\end{array}$ & \\
\hline $\begin{array}{l}1 \cdot 3-1 \cdot 4 \\
1 \cdot 5-1 \cdot 6 \\
1 \cdot 7-1 \cdot 8 \\
1 \cdot 9-2 \cdot 0 \\
2 \cdot 1-2 \cdot 2 \\
2 \cdot 3-2 \cdot 4\end{array}$ & $\begin{array}{r}68 \\
144 \\
135 \\
90 \\
41 \\
20\end{array}$ & $\begin{array}{l}52.0 \pm 7.9 \\
56.5 \pm 9 \cdot 5 \\
62.0 \pm 9.9 \\
66.7 \pm 11.6 \\
71.4 \pm 11.3 \\
84.6 \pm 16.1\end{array}$ & $\begin{array}{l}36 \\
70 \\
63 \\
54 \\
31 \\
17\end{array}$ & $\begin{array}{l}48 \cdot 7 \pm 7 \cdot 3 \\
52 \cdot 0 \pm 7 \cdot 2 \\
58 \cdot 1 \pm 10 \cdot 5 \\
60 \cdot 6 \pm 8 \cdot 4 \\
63 \cdot 5 \pm 10 \cdot 4 \\
68 \cdot 4 \pm 7 \cdot 2\end{array}$ & $\begin{array}{l}0.05>P>0.01 \\
P<0.01 \\
P<0.01 \\
P<0.01 \\
P<0.01 \\
P<0.01\end{array}$ \\
\hline
\end{tabular}

TABLE II.-Demonstration of Frequency of Normal and Near-normal Activated Partial Thromboplastin Clotting-times During Anticoagulant Treatment

\begin{tabular}{|c|c|c|c|c|c|}
\hline \multirow{2}{*}{$\begin{array}{l}\text { Prothrombin } \\
\text { Ratio }\end{array}$} & \multirow[t]{2}{*}{ Lesions } & \multirow{2}{*}{$\begin{array}{l}\text { No. } \\
\text { of } \\
\text { Tests }\end{array}$} & \multicolumn{3}{|c|}{$\begin{array}{l}\text { No. of Corresponding Plasma Activated } \\
\text { Partial Thromboplastin Clotting-times }\end{array}$} \\
\hline & & & $<50$ seconds & $<45$ seconds & $<40$ seconds \\
\hline $1 \cdot 3-1 \cdot 4\{$ & $\begin{array}{l}\text { Arterial } \\
\text { Venous }\end{array}$ & $\begin{array}{l}68 \\
36\end{array}$ & $\begin{array}{l}28(41 \%) \\
21(58 \%)\end{array}$ & $\begin{array}{r}13(19 \%) \\
9(25 \%)\end{array}$ & $\begin{array}{l}1(1.5 \%) \\
5(14 \%)\end{array}$ \\
\hline $1.5-1.6\{$ & $\begin{array}{l}\text { Arterial } \\
\text { Venous }\end{array}$ & $\begin{array}{r}144 \\
70\end{array}$ & $\begin{array}{l}33(23 \%) \\
22(31 \%)\end{array}$ & $\begin{array}{l}7(5 \%) \\
5(7 \%)\end{array}$ & $\begin{array}{l}1(0 \cdot 7 \%) \\
3(4 \cdot 3 \%)\end{array}$ \\
\hline $1.7-1.8\{$ & $\begin{array}{l}\text { Arterial } \\
\text { Venous }\end{array}$ & $\begin{array}{r}135 \\
63\end{array}$ & $\begin{array}{l}8(6 \%) \\
11(17 \cdot 5 \%)\end{array}$ & $\begin{array}{l}1(0.7 \%) \\
2(3.2 \%)\end{array}$ & $\begin{array}{l}0 \\
1(1.6 \%)\end{array}$ \\
\hline $1.9-2.0\{\{$ & $\begin{array}{l}\text { Arterial } \\
\text { Venous }\end{array}$ & $\begin{array}{l}90 \\
54\end{array}$ & $\begin{array}{l}4(4 \cdot 4 \%) \\
4(7 \cdot 4 \%)\end{array}$ & $\begin{array}{l}0 \\
0\end{array}$ & $\begin{array}{l}0 \\
0\end{array}$ \\
\hline $2 \cdot 1-2 \cdot 2\{$ & $\begin{array}{l}\text { Arterial } \\
\text { Venous }\end{array}$ & $\begin{array}{l}41 \\
31\end{array}$ & $\begin{array}{l}0 \\
2(6 \cdot 4 \%)\end{array}$ & $\begin{array}{l}0 \\
0\end{array}$ & $\begin{array}{l}0 \\
0\end{array}$ \\
\hline
\end{tabular}

pooled plasma samples during anticoagulant treatment are shown in Table III. The test is shown to have a coefficient of variation of $3 \%$ or less.

TABLE III.-Replicate Partial Thromboplastin Times, to Demonstrate

\begin{tabular}{c|c|c|c|c}
\multicolumn{1}{c}{ Degree of Variation in Various Plasma Samples } \\
\hline $\begin{array}{c}\text { Prothrombin } \\
\text { Ratio }\end{array}$ & $\begin{array}{c}\text { No. } \\
\text { of } \\
\text { Replicates }\end{array}$ & $\begin{array}{c}\text { Mean } \\
\text { Activated } \\
\text { Plasma } \\
\text { Clotting-time } \\
\text { (seconds) }\end{array}$ & \pm 1 S.D & $\begin{array}{c}\text { Coefficient } \\
\text { of } \\
\text { Variation }\end{array}$ \\
\hline 1.0 & 24 & 39.1 & \pm 1.18 & $3.0 \%$ \\
1.5 & 12 & 45.2 & \pm 1.00 & $2.2 \%$ \\
1.6 & 14 & 39.9 & \pm 1.14 & $2.9 \%$ \\
1.7 & 24 & 44.4 & \pm 0.90 & $2.0 \%$ \\
2.1 & 16 & 52.7 & \pm 1.20 & $2.3 \%$ \\
\hline
\end{tabular}

Haemorrhagic complications consisting of haematuria, severe bruising with subcutaneous haemorrhage, or gastrointestinal bleeding developed 21 times in 20 patients, either while in hospital or while attending as outpatients during 1967 . One further case is included from a previous year, though the prothrombin ratio is not strictly comparable since human brain thromboplastin was used. The prothrombin ratios taken when the patients were seen complaining of such complications are shown with the corresponding activated clotting-times in Table IV.

\section{Discussion}

Of the 10 known plasma-clotting factors (factors XII, XI, X, IX, VIII, VII, V, II, I, and XIII) the concentrations of only four are reduced by oral anticoagulants-that is, factors $\mathrm{X}, \mathrm{IX}, \mathrm{VII}$, and II). The degrees of depression of formation of these factors and the rapidity with which their plasma concentrations fall vary from factor to factor. Factor VII is rapidly and markedly reduced, and may fall to $10 \%$ of normal during the first 48 hours of treatment, while both factor II (prothrombin) and factor $\mathrm{X}$ (Stuart-Prower factor) are only reduced to $20-30 \%$ of normal by the end of the first week of treatment, and factor IX (Christmas factor) falls to about $40 \%$ of normal by the end of the first week of treatment (Denson, 1961). During the first few days of treatment the prothrombin clotting-time is prolonged, since the prothrombin reaction is extremely sensitive to changes in the plasma concentration of factor VII but is not affected at all by variations in factor IX - that is, normal results found in Christmas disease. The prothrombin reaction is also affected by marked reductions in plasma factors $\mathrm{X}, \mathrm{V}$, and II, but factor $\mathrm{V}$ is unaffected by oral anticoagulants, and factors $\mathrm{X}$ and II are only moderately reduced during the first 72 hours of oral anticoagulant treatment.

The partial thromboplastin clotting-time is prolonged by reductions in the plasma concentrations of factors XII, XI, X, IX, VIII, V, II, and I (Nye et al., 1962), and is completely unaffected by falls in factor VII, being normal in congenital factor VII deficiency. During the first few days of anticoagulant treatment factors X, IX, and II are only moderately reduced and the activated partial thromboplastin clotting test is normal or nearly normal, in contrast to the prolonged prothrombin time (which could give a false sense of adequate anticoagulant effect at this stage). If a patient is treated with heparin during the first few days of oral anticoagulant therapy the effect of circulating heparin is demonstrated by prolongation in the partial thromboplastin clotting-time (Eastham, 1962). In fact, the partial thromboplastin clotting-time is a better test than the whole-blood clotting-time for the control of heparin therapy (Spector and Corn, 1967).

From the 22 results obtained from 21 patients who showed evidence of overtreatment by haematuria or severe bruising it would appear that the partial thromboplastin clotting-time may be useful in the future avoidance of such bleeding (Table IV). 
From these few results it would seem unwise to allow the partial thromboplastin clotting-time to exceed 80 seconds, and a useful therapeutic range within which to maintain patients treated with oral anticoagulants would appear to be $60-70$ seconds, regardless of the prothrombin ratio.

Of these 21 patients who were overtreated, only seven were being treated after venous thrombosis, while 11 were being treated after myocardial infarction, and three were being anticoagulated for complications associated with mitral valve damage. It is pertinent to draw attention to the difference in results obtained from patients with arterial lesions and those with venous lesions. (Though the series is too small to be significant the results obtained from the 11 patients with mitral valve lesions appear to be very similar to those obtained from patients with arterial lesions.) The patients with arterial lesions were more fully anticoagulated, as measured by the partial thromboplastin clotting-time at given prothrombin ratio values (Table I). By contrast there was a higher frequency of normal or near-normal partial thromboplastin ratios in patients with venous lesions than in patients with arterial lesions (Table II). Though plasma surface activation in vitro is an artificial manœuvre, it is important to attempt to measure the degree of activation possible, since surface activation almost certainly occurs in vivo during activation of plasma procoagulant factors; such activation can lead to actual thrombosis before platelet thrombi develop, and can occur in the absence of obvious endothelial damage, in association with venous stasis (Wessler, 1962).

The demonstration of accurate reproducibility of the partial thromboplastin clotting test in Table III is in agreement with the findings of Goulian and Beck (1965), who showed that repeated tests on the same individual gave only slight variations over a 14-month period, whereas greater variations were obtained when results from different individuals were compared.

In the partial thromboplastin test used here (Eastham, 1962) plasma is activated by means of bentonite, though kaolin or celite could be used equally well. Optimal amounts of platelet substrate substitute in the form of a soya bean extract are used to avoid any individual variations in platelet function, but various platelet substrates or substrate substitutes give the same results, which would enable laboratories to report comparable results (Goulian and Beck, 1965).

Apart from its gross insensitivity to changes in plasma factor IX concentration, the prothrombin test suffers from lack of simple correlation of results when different thromboplastin preparations are used. The activated partial thromboplastin clotting test costs virtually only the technician labour involved when bentonite and soya bean extract are used. Minor drawbacks are that it is sensitive to variation in citrate concentration, and activation of plasma factors must be avoided by using either polystyrene containers or siliconed glassware. Providing these disadvantages are allowed for, the activated plasma partial thromboplastin clotting test appears to have many practical advantages over the prothrombin test in the control of oral anticoagulant therapy.

\section{Summary}

During 1967913 plasma samples from 103 patients on longterm oral anticoagulant therapy were tested and the activated partial thromboplastin clotting-times were compared with the corresponding prothrombin ratios. The former test has many advantages over the prothrombin estimation, since it can demonstrate incomplete anticoagulation both in the early stages

TABLE IV

\begin{tabular}{|c|c|c|c|c|c|c|c|c|}
\hline \multirow[b]{2}{*}{$\begin{array}{l}\text { Case } \\
\text { No. }\end{array}$} & \multirow[b]{2}{*}{ Age } & \multirow[b]{2}{*}{ Sex } & \multirow[b]{2}{*}{$\begin{array}{l}\text { Clinical } \\
\text { Condition }\end{array}$} & \multirow[b]{2}{*}{ Anticoagulant } & \multirow{2}{*}{$\begin{array}{l}\text { Duration of } \\
\text { Anticoagulant } \\
\text { Treatment } \\
\text { Before } \\
\text { Haemorrhage }\end{array}$} & \multirow[b]{2}{*}{$\begin{array}{l}\text { Haemorrhagic Complication of } \\
\text { Anticoagulant Treatment }\end{array}$} & \multicolumn{2}{|c|}{$\begin{array}{l}\text { (At the Time of } \\
\text { Haemorrhagic Episode) }\end{array}$} \\
\hline & & & & & & & $\underset{\text { Prothrombin }}{\text { Ratio }}$ & $\begin{array}{l}\text { Partial } \\
\text { Thrombo- } \\
\text { plastin } \\
\text { Time (sec.) }\end{array}$ \\
\hline 1 & 52 & $\mathbf{M}$ & Myocardial infarction & Warfarin & 5 months & $\begin{array}{l}\text { Subcutaneous bleeding plus probably } \\
\text { bleeding in muscles of right shoulder, } \\
\text { after throwing ball in play }\end{array}$ & 1.8 & 78 \\
\hline $\begin{array}{l}2 \\
3 \\
4\end{array}$ & $\begin{array}{l}65 \\
77 \\
60\end{array}$ & $\begin{array}{l}\mathbf{M} \\
\mathbf{M}\end{array}$ & $\begin{array}{l}\text { Myocardial infarction } \\
\text { Myocardial infarction } \\
\text { Repeated attacks of thrombo- }\end{array}$ & $\begin{array}{l}\text { Warfarin } \\
\text { Phenindione } \\
\text { Phenindione }\end{array}$ & $\begin{array}{l}12 \text { days } \\
26 \text { days } \\
27 \text { months }\end{array}$ & $\begin{array}{l}\text { Macroscopic haematuria } \\
\text { Macroscopic haematuria } \\
\text { Subcutaneous bleeding plus bruising }\end{array}$ & $\begin{array}{l}1 \cdot 8 \\
1 \cdot 8 \\
1 \cdot 8\end{array}$ & $\begin{array}{l}79 \\
80 \\
86\end{array}$ \\
\hline 5 & 67 & $\mathbf{M}$ & Myocardial infarction & Phenindione & 5 years & $\begin{array}{l}\text { Subcutaneous bleeding plus brusing, } \\
\text { especially on lower legs, plus subcon- } \\
\text { junctival haemorrhage }\end{array}$ & 1.9 & 86 \\
\hline $\begin{array}{l}6 \\
7(a) \\
8 \\
9 \\
10\end{array}$ & $\begin{array}{l}45 \\
56 \\
52 \\
53 \\
44\end{array}$ & $\begin{array}{l}\mathbf{M} \\
\mathbf{M} \\
\mathbf{M} \\
\mathbf{M}\end{array}$ & $\begin{array}{l}\text { Second myocardial infarction } \\
\text { Myocardial infarction } \\
\text { Second myocardial infarction } \\
\text { Pulmonary embolism } \\
\text { Mitral valve disease plus auri- }\end{array}$ & $\begin{array}{l}\text { Phenindione } \\
\text { Warfarin } \\
\text { Phenindione } \\
\text { Phenindione } \\
\text { Warfarin }\end{array}$ & $\begin{array}{l}20 \text { days } \\
41 \text { months } \\
40 \text { months } \\
18 \text { months } \\
33 \text { days }\end{array}$ & $\begin{array}{l}\text { Macroscopic haematuria } \\
\text { Macroscopic haematuria } \\
\text { Macroscopic haematuria } \\
\text { Macroscopic haematuria } \\
\text { Subcutaneous haemorrhages and bruis- }\end{array}$ & $\begin{array}{l}2 \cdot 0 \\
2 \cdot 0 \\
2 \cdot 0 \\
2 \cdot 1 \\
2 \cdot 1\end{array}$ & $\begin{array}{l}76 \\
89 \\
99 \\
71 \\
86\end{array}$ \\
\hline 11 & 50 & $M$ & $\begin{array}{l}\text { cular fibrillation } \\
\text { Deep leg vein thrombosis }\end{array}$ & Phenindione & 2 months & Subcutaneous haemorrhages and bruis- & $2 \cdot 2$ & 90 \\
\hline 12 & 46 & $\mathbf{F}$ & Myocardial infarction & Warfarin & 7 months & $\begin{array}{l}\text { 1ng, especially on lower legs } \\
\text { Severe subcutaneous haemorrhage and }\end{array}$ & $2 \cdot 2$ & 91 \\
\hline 13 & 62 & $\mathbf{M}$ & Second myocardial infarction & Phenindione & 6 years & Subcutaneous haemorrhages and bruis- & $2 \cdot 3$ & 88 \\
\hline 14 & 51 & $\mathbf{F}$ & $\begin{array}{l}\text { Mitral valve disease with auri- } \\
\text { cular fibrillation and femoral }\end{array}$ & Phenindione & 40 days & $\begin{array}{l}\text { ing } \\
\text { Severe macroscopic haematuria }\end{array}$ & $2 \cdot 6$ & 82 \\
\hline 15 & 51 & $\mathbf{M}$ & Deep leg vein thrombosis with & Phenindione & 50 days & Subcutaneous bruising & $2 \cdot 6$ & 82 \\
\hline 7 (b) & 56 & $\mathbf{M}$ & Myocardial infarction & Warfarin & 43 months & Severe bruising plus subcutaneous & $3 \cdot 0$ & 96 \\
\hline 16 & 40 & $\mathbf{M}$ & Pulmonary embolism after & Phenindione & 29 days & $\begin{array}{l}\text { haemorrnages } \\
\text { Macroscopic haematuria }\end{array}$ & $3 \cdot 1$ & 100 \\
\hline $\begin{array}{l}17 \\
18\end{array}$ & $\begin{array}{l}56 \\
48\end{array}$ & $\stackrel{M}{M}$ & $\begin{array}{l}\text { Second myocardial infarction } \\
\text { Repeated thrombophlebitis }\end{array}$ & $\begin{array}{l}\text { Phenindione } \\
\text { Phenindione }\end{array}$ & $\begin{array}{l}5 \text { years } \\
7 \text { years }\end{array}$ & $\begin{array}{l}\text { Macroscopic haematuria } \\
\text { Severe subcutaneous haemorrhages, } \\
\text { especially over lower legs and in }\end{array}$ & $\begin{array}{l}3 \cdot 2 \\
3 \cdot 9\end{array}$ & $\begin{array}{r}102 \\
86\end{array}$ \\
\hline 19 & 69 & $\mathrm{~F}$ & Deep leg vein thrombosis & Warfarin & 60 days & Severe macroscopic haematuria & $4 \cdot 2$ & 91 \\
\hline 20 & 74 & $\mathrm{~F}$ & Myocardial infarction & Phenindione & 3 months & $\begin{array}{l}\text { Severe melaena, which ceased when } \\
\text { anticoagulants were discontinued. } \\
\text { Blood sample obtained three days } \\
\text { after melaena started and when anti- } \\
\text { coagulants had not been taken for } \\
\text { three days }\end{array}$ & $1 \cdot 2$ & 89 \\
\hline 21 & 51 & $\mathbf{M}$ & $\begin{array}{l}\text { Mitral valve disease, auricular } \\
\text { fibrillation, and attacks of } \\
\text { emboli }\end{array}$ & Phenindione & 36 months & $\begin{array}{l}\text { The patient thought } 50 \text {-mg. tablets were } \\
\text { 10-mg. tablets, and took excessive } \\
\text { doses until he presented himself with } \\
\text { subcutaneous bruising over arms, } \\
\text { legs, and trunk }\end{array}$ & $7 \cdot 0^{*}$ & 84 \\
\hline
\end{tabular}


of treatment and also later, when the patient is apparently adequately treated according to the prothrombin ratio. It appears that patients with venous lesions require more anticoagulant to produce the same partial thromboplastin clottingtime than do patients with arterial lesions, and this may have a bearing on relapses and further thromboses. Examination of results from 21 patients when they were bleeding suggests that the partial thromboplastin clotting-time may be a better test for the detection of potential bleeding and bruising after overtreatment, since it is sensitive to variations in concentration of factor IX, a factor which does not affect the prothrombin clottingtime. It is therefore proposed that the plasma partial thromboplastin clotting-time is the more valuable test for the control of oral anticoagulant treatment, and a suggested therapeutic range of values is given.
I am grateful to my clinical colleagues for access to clinical case notes, to Dr. J. M. Naish for advice and encouragement, and to the technical staff of the haematology section for their enthusiastic assistance in this work.

\section{REFERENCES}

Biggs, R., and Denson, K. W. E. (1967). Brit. med. F., 1, 84 Denson, K. W. (1961). Brit. med. ₹., 1, 1205.

Eastham, R. D. (1962). \%. clin. Path., 15, 86.

Eastham, R. D., and Morgan, E. H. (1964). Lancet, 2, 543.

Goulian, M., and Beck, W. S. (1965). Amer. F. clin. Path., 44, 97

Nye, S. W., Graham, J. B., and Brinkhous, K. M. (1962). Amer. F. med. Sci., 243, 279.

Poller, L. (1964). Brit. med. 7., 2, 565.

Quick, A. J. (1942). The Hemorrhagic Diseases and the Physiology of Hemostasis. Springfield, Illinois.

Spector, I., and Corn, M. (1967). F. Amer. med. Ass., 201, 157

Wessler, S. (1962). Amer. F. Med., 33, 648.

\title{
Clinical Trial of Disodium Cromoglycate in Treatment of Asthma in Children
}

\author{
J. MORRISON SMITH,* M.D., F.R.C.P.ED., D.P.H., D.T.M.\&H., T.D.D.; G. F. DEVEY,* M.B., CH.B., D.P.H.
}

Brit. med. F., 1968, 2, 340-344

Disodium cromoglycate (FPL 670 ; Intal) is one of a series of chromone derivatives studied by Fisons Pharmaceuticals Limited. It has been shown to inhibit the effects of some specific types of reaginic antibody-antigen reactions. It is not an anti-inflammatory agent and it is not a bronchodilator, nor does it protect against the effect of histamine, of 5-hydroxytryptamine, or of slow-reacting substance (SRS-A).

The compound has been shown to be relatively non-toxic. In acute toxicity tests in small laboratory animals the $\mathrm{LD}_{50}$ on parenteral administration was greater than $2,000 \mathrm{mg} . / \mathrm{kg}$. In prolonged tests no toxic effects were seen, except at doses greater than $30 \mathrm{mg}$. $/ \mathrm{kg}$. Renal tubular degeneration was the only specific toxic effect noted at higher dosage. The compound is excreted rapidly in the bile and urine and there is no evidence in animals of accumulation in any tissue (Cox, 1967).

Experimentally in atopic volunteers there was a reduction of the bronchospasm induced by aerosol of the appropriate antigen when the compound was administered by inhalation previous to challenge. Only a small fraction (less than 10\%) of the inhaled dose in man is absorbed, and it is rapidly excreted. When given by mouth less than $1 \%$ is absorbed, and its protective effect is probably insufficient to be of clinical value (Altounyan, 1968).

A small double-blind crossover trial in adults showed significant clinical improvement in patients with allergic pulmonary disease (Howell and Altounyan, 1967). On the basis of this and further clinical experience which has since been reported (Altounyan and Howell, 1968) these authors concluded that disodium cromoglycate is a major advance in the management of allergic airway disease. This view was supported by Kennedy (1967) but was not shared by Grant et al. (1967). The present study was designed to evaluate the efficacy of this drug in the treatment of children suffering from asthma.

\section{Method of Administration}

A plastic inhaler (Spinhaler) has been designed for the inhalation of the drug, which is dispensed as a micronized powder

\footnotetext{
- From the Asthma Clinic, Birmingham School Health Service.
}

in gelatin capsules. The patient inhales the powder by taking a few deep breaths through the Spinhaler; in practice this appliance has proved easy to use by co-operative children even with fairly severe asthma. It is easily cleaned and maintained, and incorporates a simple means of puncturing the capsules.

\section{Plan of Trial}

The object of the trial was to compare on a double-blind basis, using crossover technique, the condition of children with asthma, present throughout the year, during two periods of four weeks each.

The children inhaled the contents of four capsules a day (on rising, at lunch-time, at tea-time, and on retiring) during the whole trial. In one four-week period the capsules contained disodium cromoglycate, in the other a placebo. The order of treatment for each patient was allocated at random and was not known to anyone concerned in the trial until the final assessments were completed. During a two-week period before the trial the children had experience in the use of the Spinhaler when they were supplied with practice capsules; initial biochemical and other observations were also made at this time.

The trial capsules were coloured pink, the practice capsules were colourless. The "active" capsules contained disodium cromoglycate $20 \mathrm{mg}$., isoprenaline sulphate $0.1 \mathrm{mg}$., and lactose $19.9 \mathrm{mg}$. The placebo capsules contained isoprenaline sulphate $0.1 \mathrm{mg}$., lactose $34.9 \mathrm{mg}$., and sodium sulphate (anhydrous) $5 \mathrm{mg}$. The practice capsules contained isoprenaline sulphate $0.1 \mathrm{mg}$. and lactose $39.9 \mathrm{mg}$.

The small dose of isoprenaline sulphate was included in the capsules to prevent bronchospasm, which may occur after the inhalation of a dry powder. Sodium sulphate was included in the placebo capsules to impart a slightly unpleasant taste similar to the "active" capsules. No other change was made in the routine treatment except when the clinical condition required an alteration in the dosage of antispasmodics or corticosteroids (see below).

Before inclusion of the children in the trial the nature of the project was carefully explained to them and their parents both 